\title{
Tuberculous fasciitis in a patient with systemic lupus erythematosus
}

\author{
Takahiko Akagi, Hiroyasu Hirano, Shunichi Fujita, Yoshitaka Morita
}

Rheumatology, Kawasaki Medical School, Kurashiki, Japan

\section{Correspondence to} Dr Yoshitaka Morita, morita@med.kawasaki-m.ac.jp

Accepted 9 July 2019

\section{DESCRIPTION}

A 42-year-old woman receiving prednisolone $(25 \mathrm{mg}$ / day) and azathioprine $(100 \mathrm{mg} /$ day $)$ presented to our clinic with fever and painful swelling of the right forearm. Seven months earlier, the patient had been diagnosed with systemic lupus erythematosus (SLE) based on the presence of arthritis, mesenteric panniculitis, leucocytopenia, antinuclear antibody and anti-dsDNA antibody. Treatment with prednisolone $(30 \mathrm{mg} /$ day) and azathioprine had improved her symptoms. However, SLE had recurred several times, requiring an increase in the dose of corticosteroids. The patient was negative for HIV and had no previous history of exposure to tuberculosis. Her body temperature was $37.8^{\circ} \mathrm{C}$ at presentation. Physical examination was unremarkable except for redness and painful swelling of the right forearm (figure 1A). Laboratory investigations revealed a $\mathrm{C}$ reactive protein level of $75.4 \mathrm{mg} / \mathrm{L}$, haemoglobin of $117 \mathrm{~g} / \mathrm{L}$, a leucocyte count of $3.97 \times 10^{9} / \mathrm{L}$ with a marked shift to the left $(30 \%$ band cells) and a platelet count of $198 \times 10^{9} / \mathrm{L}$. Liver and renal function tests were normal. Serum complement C3 and C4 concentrations were also normal. Antineutrophil cytoplasmic antibody and an interferon-gamma release assay for tuberculosis were negative. Urinalysis showed negative protein and $2+$ haematuria with some red blood cells (5-9/high-power field) and white blood cells (1-4/high-power field). Contrast-enhanced CT of the chest, abdomen and pelvis showed no abnormality. Blood culture was negative. The patient was started on treatment with intravenous antibiotics for suspected cellulitis; however, her symptoms did not improve. The swelling and redness of the right forearm worsened in the following days (figure 1B) and the patient developed painful redness on the buttocks and both thighs (figure 1C). We then performed MRI to evaluate the state of the soft tissue.

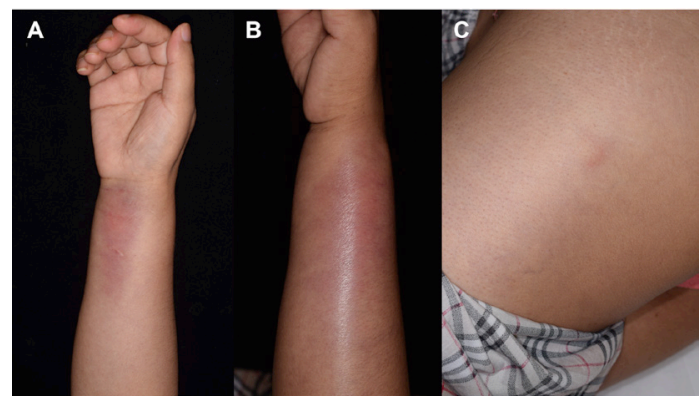

Figure 1 Painful swelling and redness of the right forearm seen on the day of admission (A). A few days later, the physical findings at the right forearm had worsened (B) and she had developed painful redness in both thighs $(C)$ as well as the buttocks.

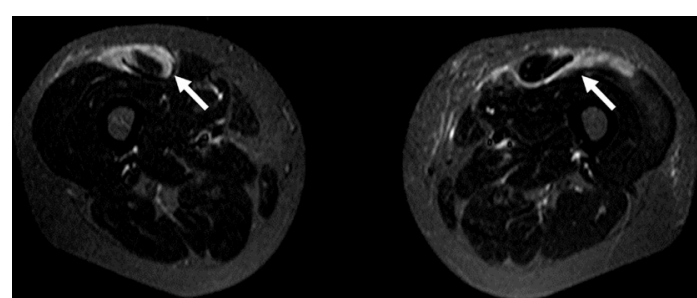

Figure 2 MRI revealed increased T2 signal intensity in the fascial layers on the anterior aspects of both thighs (arrows).

MRI of both thighs showed increased T2 signal intensity in the fascial layers (figure 2). Pathological study of a biopsy specimen from the left vastus lateralis showed extensive necrosis without epithelioid cell granuloma. Acid-fast staining revealed acid-fast bacilli, and culture of the specimen revealed Mycobacterium tuberculosis. Therefore, the patient was diagnosed with tuberculous fasciitis and her symptoms improved after starting antituberculosis therapy. The treatment was continued for 12 months, and the patient remains free of relapse 10 months after it was completed.

Tuberculous fasciitis may mimic cellulitis or autoimmune fasciitis; therefore, the diagnosis may be delayed or missed in its early stages. Although uncommon, this soft tissue infection may be encountered in immunocompromised patients, such as those with HIV infection. It has also been reported in patients receiving immunosuppressive treatment for rheumatic disease, including polymyositis and rheumatoid arthritis. ${ }^{12}$ To our knowledge, this is the first documented case of tuberculous fasciitis in a patient with SLE. Of note, it is reported that extrapulmonary tuberculosis is

\section{Patient's perspective}

I got a serious illness. Thank you for making it better.

Learning points

- Tuberculous fasciitis is uncommon but may be encountered in patients who are receiving immunosuppressive therapy for rheumatic disease.

- Tuberculous infection should be included in the differential diagnosis when an immunocompromised patient presents with soft tissue inflammation of unknown cause. 
more common than pulmonary tuberculosis in SLE patients. ${ }^{3}$ Tuberculosis fasciitis should be included in the differential diagnosis when an immunocompromised patient presents with soft tissue inflammation.

Contributors TA, HH, SF and YM involved in conception or design of the work. TA and $\mathrm{HH}$ are responsible for acquisition of data. TA, HH, SF and YM are responsible for analysis and interpretation of data. TA and YM drafted the manuscript or revised.

Funding The authors have not declared a specific grant for this research from any funding agency in the public, commercial or not-for-profit sectors.

Competing interests None declared.
Patient consent for publication Obtained.

Provenance and peer review Not commissioned; externally peer reviewed.

\section{REFERENCES}

1 Nagayama I, Nagatoya K, Kurahara Y, et al. Tuberculous fasciitis in polymyositis: a rare case of extrapulmonary tuberculosis. Intern Med 2016:55:3205-9.

2 Kwon HH, Baek SH, Park SH. Miliary tuberculosis and necrotizing tuberculous fasciitis--an unusual coexistence in a rheumatoid arthritis patient. Int J Rheum Dis 2010;13:171-4.

3 Bhattacharya PK, Jamil M, Roy A, et al. SLE and tuberculosis: a case series and review of literature. J Clin Diagn Res 2017;11:0R01-3.

Copyright 2019 BMJ Publishing Group. All rights reserved. For permission to reuse any of this content visit

https://www.bmj.com/company/products-services/rights-and-licensing/permissions/

BMJ Case Report Fellows may re-use this article for personal use and teaching without any further permission.

Become a Fellow of BMJ Case Reports today and you can:

- Submit as many cases as you like

- Enjoy fast sympathetic peer review and rapid publication of accepted articles

- Access all the published articles

Re-use any of the published material for personal use and teaching without further permission

\section{Customer Service}

If you have any further queries about your subscription, please contact our customer services team on +44 (0) 2071111105 or via email at support@bmj.com.

Visit casereports.bmj.com for more articles like this and to become a Fellow 